\title{
民办高校安全隐患问题的诊断与防治研究--以云南新兴职业学 院为例
}

\author{
杨炳金 李加磊 李地新太
}

云南新兴职业学院

DOI:10.32629/er.v3i1.2378

[摘要] 随着全国各类高校教育事业的不断发展,校园安全问题在近几年也日益乃显,越来越多的人开始关注校园安全问题。提高师生的安全 意识,提高校园安全事件防范能力,为校园安全工作提供切实可行的保障,并在一定程度上加强校园的安全文化建设,从而营造更为安全的校园氛 围。对此,笔者通过相关的调研分析,针对云南新兴职业学院所存在的安全问题,提出相应的解决方案, 以求解决云南新兴职业学院及其同类院校 存在的安全问题,并为解决民办高校安全问题提供理论基础与实践指导。

[关键词] 民办高校; 安全问题; 防范措施

\section{1 民办高校安全问题}

通过对云南新兴职业学院展开调查, 我们发现, 对校内及周边的安全 问题极为重视, 建立了安全管理制度。但仍然存在安全问题, 从学习方面 看: 学习设备较为老旧、实验器材较为老旧或器材管制不严、相关化学试 剂监管不严等; 从生活方看: 校内以及周边生活设施存在安全隐患, 比如 校园围墙常有倒塌等现象、宿舍床铺稳固存在问题、宿舍阳台护栏不稳固、 部分建筑陈旧屋顶漏水导致电路短路、黑车载客现象、公交站牌不稳等; 学生信息化方面看: 以及部分学生可能存在受到网络诈骗、金融诈骗、传 销等的侵扰, 学校内部食品安全问题重中之重, 在一定程度上只能预防不 能整治; 校内安全管理措施不够完善: 比如校内保安管制比例不够、监管 力度不够等 ${ }^{[1]}$ 。

归纳起来, 如下两大问题是民办高校基于安全防范问题重点可能存在 的问题: 首先, 民办高校普遍存在领导安全意识不到位, 对国家高校相关管 理制度的学习执行力不足, 导致学校的管理制度及管理体系不建全; 其次, 对于民办高校的资金远远不及公立高校充足, 对于部分安全设施的构建与 完善无法面面俱到, 保障体系不完善; 再次, 由于缺乏专业的管理人才队伍, 从而导致民办高校安全管理制度的建立、实施与后续完善整改工作并不规 范, 在日常工作中难免出现疏漏, 并且无法将出现情况及时解决, 技术支持 缺失。

\section{2 改善措施}

2. 1 学习方面

校内定期检查教学设施、更换老化教学设备、加强对相关教学器具、 试验品的监管力度。并形成常态化对教学设施、实验设备、材料等进行监 察、管控。建全安全问题应急处理预案 ${ }^{[1]}$ 。

\section{2 生活方面}

加强学生宿舍违规品检查力度; 加强学生宿舍设施的老化程度检查; 完善校内校外相关设施的完整程度和应用效度; 加强学生自身安全意识, 安全标语警示、开展安全教育主题讲座等; 提高对网络诈骗, 金融诈骗以 及传销等的辨识度; 提高校内食堂食品安全监管力度及完善食堂餐具消毒 措施。

2. 3校园卫生管理方面

以学生组织及社团形式进一步组建卫生监管团队, 学校后勤工作人员 与学生组织联动, 完善相关管理制度。

2. 4学生心理疾病排查

校内建立大学生心理咨询室, 聘请校外经验丰富的临床心理咨询师加
入学校心理疾病监控队伍, 针对部分心理障碍的学生进行排查、辅导、治疗。 上述相关改善措施经过小范围内的试点运行, 改善效果肉眼可见, 且 对于学生群体, 对其学习生活等方方面面有了极大程度改善, 效果显著。

\section{3 具体措施要求}

3. 1 安全隐患排查系统管理

学院应在相关部门的领导下, 对校内各区域、各部门的安全隐患内容 进行彻底排查, 并对相关内容进行记录, 在此基础上, 制定校内的安全排查 制度, 建立隐患档案并建立完善的考核制度, 从而能够更好进行接下来的 工作。

\section{2 安全隐患排查责任细分}

将安全排查等相关工作的具体责任细分到个人, 由个人牵头, 部门随 后, 进行有组织、有计划的安全隐患排查工作, 定期进行安全排查、措施施 行、效果分析、后续改善等环节, 进行短时间内多次快速的改善工作。在 此基础上, 将相关工作的责任精准定位到部门甚至个人, 从而加强相关安 全排查的效能。

\section{3 安全隐患排查工作流程}

通过我校制定的考核与安全排查制度, 记性有组织有内容的安全排查 工作, 其中主要包括: 排查计划告知、定期不定期精准排查、后续考核、 改善核销及后续检查四个步骤。

3. 4 安全隐患排查工作保障

对相关安全排查及后续措施, 都应有一系列后勤部门进行全程保障, 学 校相关部门应制定基于安全巡查的相关制度, 将各部门职责落实到位, 全力 帮扶相关部门工作, 以求安全排查工作高效稳定完成。学院相关部门应大 力配合建立安全排查档案, 并肩负维护档案的相关职责 ${ }^{[2]}$ 。学院应确保各 部门工作责任的落实情况, 督促并监督相关部门做好本职工作。加强学院 经费把控力度, 追踪相关资金的用处去向, 使经费效度最大化。

3.5 精心组织, 全面排查

安全隐患排查应在学院相关领导牵头下, 并在分管院领导直接指挥下, 由保卫处牵头, 各相关部门参与。安全隐患排查内容及责任部门: 校车 (办 公室), 教学楼、教室、电子阅览室、教学设备, (教务处), 实验室、实操室 (各系部), 体育场所及器材 (体育部), 学生宿舍防火安全、心理健康 (学生 处), 食堂、超市、煤气、锅炉、医务室、盖板等(后勤处), 消防、交通、 防溺水与校园周边环境等(保卫处)。(1)校办对校车安全性能进行排查, 司 机严格遵守交通法规, 对司机严格管理, 确保校车安全运行。(2)教务处、相 关院系对教学设备及实验室、化学危险品室进行安全隐患排查。特别是化 
学危险品实训室要按照国家标准进行建设, 专人专管, 用保险柜存放化学 危险品, 安装双保险门及双人管理保险柜的钥匙, 责任到人。(3)图书馆及图 文信息中心对管理的设备进行安全运行排查, 严防设备运行发热引起火灾, 严防管网破损漏电。(4)体育部对体育场所及器材安全性能及运行进行排查, 严禁体育场所及器材老化、破损等导致师生运动时受伤。(5)学生处对学生 宿舍安全隐患排查, 学生宿舍是学生生活的场所, 有少数学生安全意识淡 薄, 违规使用高功率的用电器, 甚至造成重大的安全事故。学生处要经常带 领辅导员对学生宿舍进行防火防盗等安全隐患排查, 加强心理咨询, 解惑心 理障碍, 消除安全隐患 ${ }^{[3]}$ 。6 后勤管理处对食堂、超市、煤气、医务室等进 行食品药品等安全隐患排查, 消除安全隐患。(7)保卫处对校园消防、交通、 校园周边环境等进行安全隐患排查, 消除安全隐患, 主要排查内容可聚焦在 与师生学习生活较为密切的设施设备, 比如食堂、宿舍、公交站点等。

3. 6 排查的主要方式和方法

通过后勤、保卫处牵头, 由多部门轮流, 进行校内校外全面勘察, 主要 通过调查研究方法与演绎归纳方法相结合, 通过直接或者间接的实地观 察、交流访谈、互动座谈、安全知识问卷调查等手段获得资料, 并对采集 的资料 (信息) 进行整理数据分析, 对整理好的资料进行数据统计, 最终得 出排查结论 ${ }^{[2]}$ 。对排查的安全隐患, 要查出原因、可能发生的不良后果等 因素。及时整改, 及时消除安全隐患。

高校校园安全是国家整体安全工作当中的组成部分, 而对于当前国内 校园问题凸显的情况下, 对安全问题的重视以及相关问题的改善就显得尤 为重要, 从而如何建立一个更加适合于学生学习和成长的和谐校园环境, 是相关部门应该深入思考的问题。

\section{4 防范措施实施}

4. 1 第一阶段

通过对国内外现行的相关调研方式进行选取, 并针对本校实际情况, 进行调研方式以及相关文件的制定。对调研过程中必须应用到以及可能用 到的相关设施进行排查和维修, 确保调研过程高效且稳定。

4. 2 第二阶段

对校内调研过程中, 涉及到的相关设施设备进行针对性维修, 并建立完 善的排查、报备、维修体系, 建立台帐, 从而在对校内公共财产的保障问题 上, 具有严格的把控能力, 切实维护学校的经济权益。通过对校内大学生校 内安全隐患问题问卷调查, 分类整理作为各项安全管理制度的理论基础。

4. 3 第三阶段

对国内外高校相关安全隐患治理方式的进一步解读, 并对相关数据进 行一定程度的收集与分析, 从而针对性做出适合于本校安全防范计划。并 建全高校安全稳定事件的应急处置过程, 通过教育引导、依法行政、技术 防范等手段, 尽可能的防止安全事故和不稳定事件的发生。应急准备过程 的目的是假设事故或事件发生后, 高校为开展科学有效的行动而事先准备 的工作, 包括应急的组织结构、资源准备、情景演练、人员培训、各种事 故或事件的应急预案等。如校园传染病等公共卫生事件应急准备过程, 学 校应建立相应的组织机构, 明确学校职能部门在应急准备过程中的基本职 能, 配备一定数量的观察隔离病房, 事先准备预防疾病传播的口罩等防控 物品, 建立应急预案等。一旦事件发生, 才可能在短期内作出反应, 有效控 制事态。

4. 4 第四阶段

对相关安全处置演练活动进行前期宣传, 老师对本班学生进行相关活 动内容、注意事项等进行详细讲解, 务必确保安全处置演练过程中出现不 可预知的问题。及时展开校园安全教育活动, 活动形式包括但不限于: 安
全讲座、安全教育周等, 形成规范的督导检查与培训制度, 建立学校公共、 学生个人财产保护安全制度, 进一步落实校园安全责任管理制度。定期全 面排查校园安全隐患并及时改善, 从根源遏制安全隐患的发生。在此基础 上, 通过对本校出台的实施方案进行合理实施和应用, 加强校园内安全环 境的建设。

4. 5第五阶段

在安全处置演练过程中, 设置专人培训及进行标准化演练现场效果的 评测, 并对演练结果进行总结, 针对本校现实情况进行相应的总结与分析, 对比演练前后全校师生在校内安全隐患防范能力的效果, 从而能够对后续 的相关工作做出指导。

4. 6 第六阶段

针对安全隐患问题分类, 整理各项目问题, 并且进行逐一的演练实施 防范。将防范效果和实际存在安全隐患问题进行结果比较分析, 呈现理论 文字, 作为民办高校安全防范工作的实践基础。

\section{5 结论}

(1) 立足于云南新兴职业学院校内安全管控实施, 完成校内安全稳定 事件的应急处置办法, 包括: 事故预防、应急准备、应急响应和应急恢复。 上报学校管理部门, 建案立档, 形成学校的政策制度 ${ }^{[4]}$ 。

(2) 打造特色教育体系, 增强校内安全防范机制。在校内建立并举行长 期有效的校园安全活动宣传月, 每年定期开展校园安全活动, 诨头引领校 内各安全职能部门领导, 下到学生的生活中、学习中, 院级领导在校园开展 讲座、安全教育等活动。特邀律师顾问及公安系统专员到校内进行安全教 育讲座, 引领并督促学校建立更为完善的安全防范机制, 寻求政府援助建 立切实可行的督导检查与安全培训制度 ${ }^{[5]}$ 。

(3) 改善校园环境, 提升学生安全意识。对云南新兴职业学院校园环境 建设提供切实可靠的理论依据, 在此基础上改善校园安全环境, 提升广大 在校师生安全意识。

（4）建立民办高校安全工作质量管理体系: 其构建从宏观层面而言包 括三个子系统: 一是高校安全工作质量管理系统; 二是高校安全工作质量 管理保障系统; 三是高校安全工作质量管理技术系统。为民办高校安全隐 患问题的防治提供有效的实践基础。

[参考文献]

[1]苏丽.西安民办高校学生安全管理问题与对策研究 [D].陕西师范大 学,2018,(01):78.

[2]孙运亭.基于 AHP 评价模型的校园安全评价体系的构建及应用 [D]. 湖北工业大学,2019,(09):55.

[3]刘铭华,梅高强.民办高校安全体系构建探究 [J].学校党建与思想教 育,2018,(08):94-96.

[4]刘莹,李淑华.新形势下民办高校学生安全教育体系的构建一一以 北京城市学院为例[J].教育现代化,2019,6(69):121-122.

[5]王利宁.民办高校治理模式创新研究[D].西北大学,2019,(01):75.

\section{作者简介：}

杨炳金(1979--), 男, 汉族,云南通海人, 本科,讲师,研究方向：医学 技术类教育教学管理、学校安全及管理研究。

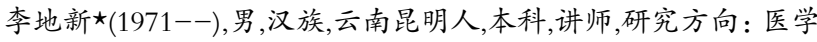
技术类教育教学管理、学校安全管理研究。

\section{基金项目:}

本文系云南省教育后勤课题: 民办高校安全隐患排查与防范措施一 以云南新兴职业学院为例(项目编号: YNJHYB20190026)的研究成果。 